Grzegorz Prus OSPPE

\title{
Maryjna posługa paulinów jasnogórskich w okresie potrydenckim
}

\section{Konieczna reforma}

Kościół katolicki początku XVI wieku potrzebował koniecznych reform, aby oczyścić swoje szeregi z ciążących nadużyć, ożywić gorliwość duszpasterską i zdynamizować formy działania. Reformy te w ograniczonym zakresie zostały podjęte już od początku tego wieku. Chęć ich realizacji zadeklarowano na Soborze Lateraneńskim V, który obradował w latach 1512-1517. Jednakże działania te okazały się zupełnie nieskuteczne. Wybuch reformacji zapoczątkowany wystąpieniem Marcina Lutra w roku 1517 i dynamiczny rozwój licznych prądów reformacyjnych stały się bodźcem do podjęcia konkretnych i skutecznych działań odnowy Kościoła na zachodzie. Wydarzeniem o znaczeniu epokowym okazał się zwołany przez papieża Pawła III i kontynuowany przez jego następców sobór powszechny w Trydencie w latach 1545-1563. To tam wypracowano odpowiedzi na nauki reformatorów, podjęto zasadnicze kwestie teologiczne i powzięto istotne postanowienia dyscyplinarne w celu odnowy życia kościelnego. Niestety nie udało się na soborze doprowadzić do powrotu, do jedności Kościoła zachodniego. Podziały powstałe w wyniku reformacji okazały się trwałe. W Kościele podjęto jednak w tym czasie szereg działań, szczególnie na soborze i po jego zakończe- 
niu, zwłaszcza za pontyfikatów Piusa V, Grzegorza XIII i Sykstusa $V$, w celu przezwyciężenia kryzysu, odzyskania wiernych utraconych na rzecz nowo powstałych wspólnot chrześcijańskich, wykazania błędów reformatorów protestanckich i zneutralizowania ich wpływu (tzw. kontrreformacja) oraz praktycznego zrealizowania długo oczekiwanej wewnętrznej reformy życia kościelnego. Działania objęły kwestie: doktrynalne, liturgiczne, prawne, dyscyplinarne, duszpasterskie, odnoszące się do życia zakonnego etc. $^{1}$

\section{Zakon paulinów w okresie potrydenckim}

W tym czasie Zakon Świętego Pawła Pierwszego Pustelnika (zakon paulinów) był dojrzałą organizacyjnie wspólnotą o kilkuwiekowej tradycji. Organizacyjnie składał się z kilku prowincji: węgierskiej, polskiej, szwabskiej i istryjskiej. Prowincja polska była wówczas rozwiniętą organizacyjnie i liczbowo społecznością, a klasztor jasnogórski posiadał już wówczas wyjątkową rangę wśród wszystkich miejsc kultu chrześcijańskiego na terenach Rzeczypospolitej. Do takiej pozycji tego sanktuarium przyczyniła się w sposób decydujący sławna obrona przed Szwedami w roku 1655, ale i wcześniej miejsce to miało rangę uprzywilejowanego miejsca kultu maryjnego, umiłowanego szczególnie przez przedstawicieli dynastii Jagiellonów. Konieczne reformy związane z postanowieniami Soboru Trydenckiego podjęto od lat dwudziestych, a konkretne efekty w postaci nowych konstytucji uzyskano w latach czterdziestych XVII wieku. W latach

1 Por. P. Pierrard, Historia Kościoła Katolickiego, Warszawa 1984, s. 201-210; J. Delumeau, Reformy chrześcijaństwa w XVI i XVII w., t. 2, Katolicyzm między Lutrem a Wolterem, Warszawa 1986, s. 7-59; K. Schatz, Sobory powszechne. Punkty zwrotne w historii Kościoła, Kraków 2002, s. $158-210$. 
1644-1646 ukazały się ich dwa wydania ${ }^{2}$. Do zrealizowania tego dzieła w sposób decydujący przyczyniła się prowincja polska na czele z pierwszymi polskimi generałami zakonu o. Marcinem Gruszkowiczem (zm. 1636) ${ }^{3}$ i o. Mikołajem Staszewskim (zm. 1658) $)^{4}$. Czas reform trydenckich oraz kontrreformacji to dla paulinów, w tym także polskiej prowincji, okres podejmowania nowych zadań: duszpasterskich, naukowych, kulturalnych. $\mathrm{Na}$ Jasnej Górze był to czas wytężonej pracy duszpasterskiej na różnych płaszczyznach. W czasie naznaczonym podejmowanymi przez reformacyjnych krytyków napaściami słowem mówionym i pisanym na formy pobożności katolickiej, w tym także te odnoszące się do kultu Matki Bożej, paulini pozostali wierni swojej Pani jako obrońcy Jej czci oraz tradycji kultu maryjnego w Kościele ${ }^{5}$. Ich cześć dla Matki Najświętszej wyraziła się także poprzez zrealizowanie w tym czasie licznych inicjatyw budowlanych mających na celu poprawę funkcjonowania sanktuarium, jego upiększenie oraz konieczne zabezpieczenie ${ }^{6}$. Gorliwie podejmowali posługę sakramentalną i kaznodziejską wobec piel-

2 S. Chodyński, Paulini; Paulini w Polsce, w: Encyklopedia kościelna, red. M. Nowodworski, t. 18, Warszawa 1892, s. 416-418; F. Pasternak, Historia kodyfikacji Konstytucji Zakonu Paulinów od 1308 do 1930 roku, „Nasza Przeszłość” XXXI (1969), s. 41-57; G. Prus, O. Marcin Gruszkowicz (ok. 1601-1636). Pierwszy polski generał zakonu paulinów, „Biuletyn Biblioteki Jagiellońskiej”, R LVI-LVII (2006-2007), s. 89-91.

3 Generał zakonu w latach 1632-1636. AJG (Archiwum na Jasnej Górze) 77, 358-359; G. Prus, O. Marcin Gruszkowicz (ok. 1601-1636). Pierwszy polski generał zakonu paulinów, „Biuletyn Biblioteki Jagiellońskiej”, R LVI-LVII (2006-2007), s. 89-91; o. J. Płatek, Polscy Generałowie Zakonu Paulinów, Częstochowa 2014, s. 11-22.

4 Generał zakonu w latach 1640-1644. AJG 77, s. 7-8, 396; J. Płatek, Polscy Generałowie Zakonu, s. 25-34.

5 Por. J. Zbudniewek, Paulini XVI i XVII wieku w dziele szerzenia kultu maryjnego, „Studia Claromontana” XXIII (2005), s. 103-111.

6 Por. J. Golonka, Budownictwo i sztuka Jasnej Góry do połowy XVII wieku, w: Częstochowa. Dzieje miasta i klasztoru jasnogórskiego. Okres staropolski, t. 1, red. F. Kiryk, Częstochowa 2002, s. 261-277; Z. Rozanow, E. Smu- 
grzymów odwiedzających sanktuarium. Jednali z Bogiem powracających na łono Kościoła katolickiego. Starali się o splendor sprawowanej w sanktuarium służby bożej, m.in. poprzez okazałą oprawę muzyczną. Wydawali drukiem publikacje o tematyce maryjnej. A gdy trzeba było, to bronili czci Najświętszej Dziewicy, ochraniając sanktuarium przed szwedzkim najeźdźcą i ryzykując swoim życiem.

\section{Pogromczyni herezji}

Na Jasnej Górze, w kaplicy cudownego obrazu Matki Bożej znajduje się bardzo charakterystyczny dla okresu kontrreformacji obraz. Został on namalowany w roku 1656, a w późniejszym czasie kilkakrotnie przemalowywany i konserwowany. Treści, które jego autor wyraził w plastycznej formie, ukazują ideę zmagania o istotne wartości wiary, w którym przyszło wówczas wziąć udział Chrystusowym wyznawcom, także na polskiej ziemi. Na obrazie wyrażono również obecność na polu tej walki paulińskich zakonników i ich rolę, jaką mieli do spełnienia. Najważniejszym przesłaniem zawartym w treści obrazu było przekonanie, że zwycięstwo w tym duchowym boju jest możliwe tylko pod opieką Bożej Rodzicielki.

Obraz znajduje się we wnętrzu barokowej części kaplicy Matki Bożej, na jej wschodniej ścianie pod gzymsem, w łuku tęczowym. Jest monumentalny, posiada wymiary $750 \times 400 \mathrm{~cm}$. Namalowany został farbami olejnymi na płótnie. Nosi znamienny tytuł Pogromczyni herezji. Pośrodku obrazu, na skłębionych obłokach, znajduje się wizerunek Matki Bożej z Dzieciątkiem, w sukni, płaszczu i koronie na rozpuszczonych włosach. Dzieciątko jest namalowane prawie nagie, w pozycji stojącej, opiera się na lewym

likowska, Zabytki sztuki Jasnej Góry. Architektura. Rzeźba. Malarstwo, Katowice 2009, s. 15-17. 
ramieniu Matki i trzyma w ręku kulę ziemską zwieńczoną krzyżem. Po prawej stronie Maryi i Jezusa znajdują się przedstawienia następujących postaci również przebywających na obłokach niebieskich: św. Augustyn w stroju biskupim trzyma w dłoni gorejące serce; św. Ambroży z otwartą księgą; trzej zakonnicy z atrybutami wiedzy teologicznej (otwarte księgi i pióro), a są to święci: Bonawentura, Anzelm z Canterbury i Bernard z Clairvaux. Po lewej stronie Bożej Matki znajdują się wizerunki: św. Hieronima z obnażonym torsem; o. Stanisława Oporowskiego (zm. 1552), świątobliwego i światłego kaznodziei paulińskiego, zwanego błogosławionym7 ; św. Grzegorza I Wielkiego w stroju pontyfikalnym; św. Tomasza z Akwinu w habicie dominikańskim, ze słońcem na piersiach; św. Alberta Wielkiego w szatach biskupich z księgą na kolanach. W dali widoczna jest postać niezidentyfikowanego biskupa. Po obu stronach Matki Bożej dostrzegamy dwóch archaniołów: Michała w hełmie na głowie i z mieczem w prawej ręce oraz Gabriela, w długiej szacie, z wysoko wzniesioną lewą ręką. Nad postacią Maryi unoszą się dwa aniołki trzymające wstęgi z napisem: Cunctas haereses i sola interemisti - „wszelkie herezje” „sama zwyciężałaś”. Na tle obłoków widać uskrzydlone główki aniołów. Poniżej, na ziemi uskrzydlony smok o wydłużonym ogonie ziejący ogniem oplata grupę osób, w których dopatrzeć się można głównych twórców reformacji. Dwie łapy zakończone pazurami smok wspiera na głowach postaci wyobrażających Marcina Lutra i Jana Kalwina, a ogonem oplata wizerunek Filipa Melanchtona. Obok tych postaci znajduje się wyobrażenie niezi-

7 AJG 77, s. 332; A. Eggerer, Fragmen panis corvi protoeremitici seu reliquiae annalium Eremi - Coenobiticorum Ordinis Fratrum Eremitarum Sancti Pauli Primi Eremitae, Viennae 1663, wyd. w tłum. P. Kosiaka jako Roczniki Paulińskie, t. 1, 1992, s. 224; J. Zbudniewek, Stanisław z Oporowa, zwany błogosławionym, w: Polscy święci, t. 5, red. J. Bar, Warszawa 1985, s. 32-60; tenże, Żywot i cuda o. Stanisława z Oporowa zwanego błogosławionym na zapleckach choru kanonicznego na Jasnej Górze, „Studia Claromontana" XXXII (2015/2016), s. 37-85. 
dentyfikowanego mężczyzny, który jest okolony ciałem smoka na wysokości szyi. Dwaj inni mało widoczni mężczyźni siedzą w cieniu skrzydeł smoka. Po lewej stronie obrazu znajduje się wizerunek proroka Izajasza w długich szatach, który w lewym ręku trzyma wstęgę z inskrypcją: QUOMODO CECIDISTI LUCIFER (Iz. 14,12) - „Jakże upadłeś, Lucyferze”, a prawą ręką wskazuje na herezjarchów. Obok Melanchtona, z prawej strony płótna, jest umieszczony wizerunek Jana Fryderyka, elektora saskiego w stroju szwedzkim, wskazującego w stronę jednego $\mathrm{z}$ trzech miast znajdujących się na drugim planie obrazu. Miasta te interpretuje się jako Genewę, Wittembergę i Wartburg. Życie i działalność głównych reformatorów, których podobizny znalazły się na omawianym obrazie, były związane właśnie z tymi miastami ${ }^{8}$. Według o. Janusza Zbudniewka autorem tego monumentalnego dzieła o ściśle kontrreformacyjnej treści obrazu miałby być pauliński malarz, o. Felicjan Ratyński ${ }^{9}$.

\section{Zmiany architektoniczne i upiększanie sanktuarium}

Sobór Trydencki postawił sztuce nowe zadania. Miała ona reprezentować Kościół, okazywać jego potęgę, przez dostrzegalne, zmysłowe piękno mówić o pięknie Boga niewidzialnego, czyli o pięknie transcendentnym ${ }^{10}$. W omawianym okresie paulini,

8 J. Golonka, Dekoracja malarska Kaplicy Jasnogórskiej z w. XVII, „Jasna Góra" (1989) 2, s. 36-37. Według innej interpretacji szpony smoka spoczywają na głowach Lutra i Zwinglego, a postacie oplecione ciałem smoka to Kalwin i Melanchton, natomiast oprócz wyżej wymienionych miast na obrazie ma się znajdować jeszcze Zurych, por. Z. Rozanow, E. Smulikowska, Zabytki sztuki Jasnej Góry, s. 80.

9 J. Samek, J. Zbudniewek, Klejnoty Jasnej Góry, Warszawa 1982, s. 34. Na temat o. F. Ratyńskiego zob. informacje w punkcie 4.

10 B.J. Wanat, Architektura barokowa klasztorów w Małopolsce, zbudowanych w XVII i XVIII wieku według własnych przepisów zakonnych, w: Kultura 
podobnie jak i inne zakony na terenie Rzeczypospolitej, znacznie rozwinęli swoją działalność w zakresie sztuki sakralnej. W tym okresie w sztuce europejskiej dominował barok, który dla ludzi Kościoła katolickiego czasu odnowy trydenckiej okazał się plastyczną formą przekazu podstawowych treści wiary. Zmiany architektoniczne na Jasnej Górze z tego czasu wpisują się w szeroką panoramę paulińskich dokonań w dziedzinie sztuki w skali nie tylko polskiej, ale i całego zakonu. Za przeoratu o. Andrzeja Żymicjusza (zm. 1625) na Jasnej Górze w roku 1620 odbyło się spotkanie króla Zygmunta III Wazy z wysłannikami cesarza Ferdynanda II Habsburga, arcyksięciem austriackim Karolem biskupem wrocławskim oraz hrabią Altheimem, w czasie którego podjęto decyzję o budowie obwarowań twierdzy jasnogórskiej ${ }^{11}$. Prowincjał o. Paulin Kłodawski (zm. 1651) zrealizował budowę nowej apteki, która miała służyć miejscowemu konwentowi i pielgrzymom ${ }^{12}$. Ojciec Andrzej Gołdonowski (zm. 1660), pełniąc kolejno różne funkcje na Jasnej Górze oraz $\mathrm{w}$ czasie swojego prowincjalatu ufundował prawie wszystkie boczne ołtarze kościoła jasnogórskiego (sześć lub osiem, oprócz ołtarza św. Pawła I Pustelnika); miał udział w pracach fortyfikacyjnych twierdzy w latach 1631-1648, rozbudowie klasztoru, powiększeniu i unowocześnieniu kościoła jasnogórskiego, ufundowaniu dla niego nowego wielkiego ołtarza oraz rzeźbionych stalli, podwyższeniu wieży, rozbudowie kaplicy Matki Bożej za sprawą fundacji Łubieńskich w latach 1641-1644 poprzez wzniesienie trzynawowego barokowego korpusu głównej części kapli-

intelektualna w zakonach polskich w XVII i XVIII wieku, red. M. Łobozek, Kraków 2006, s. 151.

11 Cathalogus patrum et fratrum vivorum quam defunctorum, 1552-1786, AJG 77, s. 346-347; J. Zbudniewek, Żymicjusz Andrzej, w: Słownik polskich teologów katolickich, t. 4, Warszawa 1983, s. 561; R.H. Bochenek, Twierdza Jasna Góra, Warszawa 1997, s. 31.

12 AJG 77, s. 9-10, 375-376; W. Szczepański, Apteka jasnogórska, „Studia Claromontana" II (1981), s. 334-335. 
cy jako przedłużenia najstarszej jagiellońskiej jeszcze jej części, wzniesieniu nowego hebanowo-srebrnego ołtarza dla cudownego obrazu Matki Bożej z fundacji kanclerza Jerzego Ossolińskiego w latach $1648-1651^{13}$. Z inicjatywy długoletniego zakrystianina o. Romualda Dymalskiego (zm. 1685) ufundowano do kościoła jasnogórskiego sześć nowych nastaw ołtarzowych i nowe ławki dla wiernych oraz dwie nastawy dla ołtarzy bocznych w kaplicy Matki Bożej ${ }^{14}$. Po katastrofalnym w skutkach pożarze Jasnej Góry w roku 1690 o. Tobiasz Czechowicz (zm. 1703), wielokrotny przeor i prowincjał, doprowadził do odbudowy wieży, budowy kościoła jasnogórskiego w stylu barokowym oraz zrealizował restaurację kaplicy Matki Bożej i sali rycerskiej ${ }^{15}$. Przy tej grupie ojców trzeba wspomnieć także o tych, którzy zasłużyli się dla rozbudowy fortyfikacji jasnogórskich, w tym wielkiego obrońcę sanktuarium o. Augustyna Kordeckiego (zm. 1673) ${ }^{16}$.

Wśród paulinów nie zabrakło też artystów malarzy, którzy tworzyli dla Jasnej Góry. Ojciec Felicjan Ratyński (zm. 1688), ma-

13 AJG 77, s. 3-4, 401-402; J. Zbudniewek, Fundacje Paulinów w XVII i XVIII wieku, „Saeculum Christianum” I (1994) 2, s. 68-69; J. Golonka, Ołtarz Jasnogórskiej Bogurodzicy, s. 59-60, aneksy źródłowe: s. 332-346, 376-381; G. Prus, Życie i twórczość o. Andrzeja Gołdonowskiego, Kraków 2001, maszynopis, s. 109-173; M. Wardzyński, Snycerski wystrój korpusu nawowego i kaplic bazyliki jasnogórskiej w XVII stuleciu, „Studia Claromontana" XXI (2003), s. 592-608; G. Prus, Polska prowincja paulinów $w$ czasie panowania dynastii Wazów w Polsce (1587-1668). Studium nad składem personalnym paulinów polskich, Częstochowa 2011, s. 96-97, 118-119, 185.

14 AJG 77, s. 15-16, 460-461; M. Wardzyński, Snycerski wystrój korpusu nawowego, s. 592-594, 604-608; G. Prus, Polska prowincja paulinów, s. 213.

15 AJG 77, s. 48, 522; M. Benger, Annalium Eremi - Coenobiticorum Ordinis Fratrum Eremitarum S. Pauli Primi Eremitae, vol. 2, Posonii 1743, wyd. w tłum. P. Kosiaka jako Roczniki Paulińskie, t. 2, Częstochowa 1997, s. 274-275; J. Zbudniewek, Czechowicz Tobiasz, w: Encyklopedia katolicka, t. 3, Lublin 1979, s. 796; G. Prus, Polska prowincja paulinów, s. 122, 242. 16 AJG 77, s. 13-14, 429-435; R.H. Bochenek, Twierdza, s. 36, 62. 
larz i pozłotnik, namalował obrazy do bocznych ołtarzy kościoła jasnogórskiego. Ołtarze te również pokrył czarną polichromią oraz złoceniami. Był autorem licznych kopii obrazu Matki Bożej Jasnogórskiej, które paulini ofiarowywali różnym kościołom, pałacom królewskim, książęcym i magnackim. Prawdopodobnie malował też sceny z życia Matki Bożej i eremitów. Część jego spuścizny malarskiej spłonęła w wyniku pożaru Jasnej Góry w roku 1690. Jest autorem obrazów zdobiących kaplicę Matki Bożej na Jasnej Górze: Ucieczka Szwedów spod Jasnej Góry (ok. 1656-1657) oraz być może, o czym była mowa wyżej, Pogromczyni Herezji. Prawdopodobnie jest także autorem innych prac znajdujących się w klasztorze jasnogórskim: grupy portretów prowincjałów paulińskich; pierwszych obrazów z serii przedstawiającej sceny historyczne (w Sali Rycerskiej); części płócien ze scenami z życia eremitów zdobiących zakrystię ${ }^{17}$. Bracia zakonni: Antoni Dobrzyński (zm. 1644) ${ }^{18}$, Izydor Leszczyński (zm. 1645) ${ }^{19}$ i Tybur-

17 AJG 77, s. 41, 470-471; J. Golonka, Dekoracja malarska kaplicy jasnogórskiej z XVII wieku, w: W kierunku chrześcijańskiej kultury, red. B. Bejze, Warszawa 1978, s. 694-695; J. Samek, J. Zbudniewek, Klejnoty Jasnej Góry, s. 34-35; M. Wardzyński, Snycerski wystrój korpusu nawowego, s. 604, 614; G. Prus, Polska prowincja paulinów, s. 121, 235.

18 AJG 77, s. 7-8, 364-365; J. Zbudniewek, Dobrzyński Jan Antoni, w: Słownik artystów polskich i $w$ Polsce działajacych (zmarłych przed 1966 r.). Malarze, rzeźbiarze i graficy, t. 2, Wrocław 1975, s. 71; J. Samek, J. Zbudniewek, Klejnoty Jasnej Góry, Warszawa 1982, s. 33; G. Prus, Polska prowincja paulinów, s. 116, 198.

19 AJG 77, s. 9-10, 364-365; J. Samek, J. Zbudniewek, Klejnoty Jasnej Góry, s. 33-34; J. Zbudniewek, Leszczyński (Lesczyński) Szymon, w: Słownik artystów polskich i w Polsce działajacych (zmartych przed 1966 r.). Malarze, rzeźbiarze i graficy, t. 5, Warszawa 1993, s. 67; tenże, Leszczyński Szymon, w: Encyklopedia katolicka, t. 10, Lublin 2004, s. 862; J. Golonka, Budownictwo i sztuka Jasnej Góry, s. 272-273; M. Wardzyński, Snycerski wystrój korpusu nawowego, s. 598-600; U tronu Królowej Polski. Jasna Góra w dziejach kultury i duchowości polskiej. Katalog wystawy pod kierunkiem J. Golonki, P. Mrozowskiego, J. Żmudzińskiego, Warszawa 2007, s. 92; G. Prus, Polska prowincja paulinów, s. 117, 200. 
czy Nowakowicz (zm. 1647) ${ }^{20}$ wykonali w latach dwudziestych XVII wieku obrazy do ołtarzy kościoła jasnogórskiego, a następnie w latach trzydziestych tego wieku serię 45 portretów imaginacyjnych wybitnych paulinów dla klasztoru jasnogórskiego ${ }^{21}$.

Na Jasnej Górze przyjął się w tym czasie zwyczaj dekorowania cudownego obrazu wotami ofiarowanymi Matce Bożej przez pielgrzymów. Już na szesnastowiecznych drzeworytach, które są najstarszymi podobiznami jasnogórskiego wizerunku, dostrzec można umieszczone bezpośrednio na obrazie klejnoty. Praktyka umieszczania tych wotów na powierzchni malowidła nie była dla zachowania wizerunku obojętna. Zawieszano je bowiem na przybijanych do obrazu gwoździach. Sytuację poprawiło nieco wprowadzenie sukienek, które były zdobione przez większą liczbę precjozów i przytwierdzane do obrazu kilkoma zaledwie gwoździami. Pierwsze takie sukienki w latach 1645-1685 miał wykonać br. Klemens Tomaszewski (zm. 1686), hafciarz, autor wielu szat liturgicznych dla kościoła jasnogórskiego. Sporządził on pierwsze trzy sukienki na obraz Matki Bożej (M. Michałowska opowiada się za czterema, J. Golonka pisze o dwóch), wykonane z fiołkowego aksamitu. Były one w późniejszym czasie przerabiane i upiększane ${ }^{22}$. W wieku XVIII jasnogórski złotnik br. Makary Sztyftowski (zm. 1740) wykonał specjalny stelaż, za pomocą którego umieszczał sukienki mocowane bolcami lub śrubami przytwierdzonymi

20 AJG 77, s. 9-10, 366-367; J. Zbudniewek, Nowakowicz Tyburcy, s. 166-167; M. Karpowicz, Nowakowicz (Nowakowic) Aleksy, w: Polski Stownik Biograficzny, t. 23, Wrocław 1978, s. 274; J. Samek, J. Zbudniewek, Klejnoty Jasnej Góry, s. 33-34; 59-62; M. Wardzyński, Snycerski wystrój korpusu nawowego, s. 598-600; J. Golonka, Budownictwo i sztuka Jasnej Góry, s. 272-273; G. Prus, Polska prowincja paulinów, s. 117, 202.

21 G. Prus, Polska prowincja paulinów, s. 116-117.

22 AJG 77, s. 23-24, 463; J. Samek, J. Zbudniewek, Klejnoty Jasnej Góry, s. 29, 58; M. Michałowska, Brat Makary Sztyftowski i jego twórczość artystyczna, „Studia Claromontana” III (1983), s. 366; J. Golonka, Budownictwo i sztuka Jasnej Góry, s. 274; W. Kurpik, Częstochowska Hodegetria, Łódź-Pelplin 2008, s. 196-197. 
na stałe na ramie obrazu. Wypracowane przez niego rozwiązanie jest stosowane do dzisiaj. Według tradycji zakonnej wykonał on dwie sukienki z okazji koronacji obrazu w roku 1717 (diamentową i rubinową), zachowane do dnia dzisiejszego ${ }^{23}$.

\section{Duszpasterstwo jasnogórskie}

Wśród podejmowanych działań paulini realizowali swoje obowiązki duszpasterskie w sanktuarium, do których należało przede wszystkim udzielanie wiernym sakramentów świętych, szczególnie celebrowanie mszy św. i sakramentu pokuty, prowadzenie nabożeństw oraz posługa kaznodziejska. Wśród licznie napływających do sanktuarium pielgrzymów znajdowali się również ludzie, którzy zdążyli już przejść na pozycje protestanckie, a teraz chcieli wrócić na łono Kościoła katolickiego. Przed obliczem Matki Najświętszej znajdywali drogę do nawrócenia. Tutaj wielką rolę do spełnienia mieli kaznodzieje jasnogórscy oraz spowiednicy.

Spowiednictwo było traktowane już wówczas jako jedno z najważniejszych zajęć paulinów. W potrydenckich konstytucjach paulińskich z roku 1644, wzorem dawniejszych ustaw, znajdował się specjalny rozdział poświęcony tej posłudze, w którym szczegółowo opisano obowiązki spowiednika ${ }^{24}$. Na Jasnej Górze posługa ta była szczególnie istotna dla licznie przybywających tam pielgrzymów. Starano się zapewnić spowiedników nie tylko pielgrzymom posługującym się językiem polskim, ale i wiernym innych narodowości (posługujących się językami: niemieckim i francuskim). Konieczne było zapewnienie odpowiedniego kształcenia

23 AJG 77, s. 101, 616; M. Michałowska, Brat Makary, s. 366-367; J. Golonka, Budownictwo i sztuka Jasnej Góry, s. 274; W. Kurpik, Częstochowska Hodegetria, s. 196-197.

24 Consitutiones Religionis S. Pauli Primi Eremitae... Romae 1644, s. 109-113; S. Szafraniec, Konwent paulinów jasnogórskich 1382-1864, Rzym 1966, s. 64. 
zakonnikom w zakresie teologii moralnej, nie tylko przed święceniami, ale praktycznie permanentnej formacji w tym zakresie, o co w klasztorze jasnogórskim gorliwie się starano. Spowiednicy dzielili się na zwyczajnych i nadzwyczajnych ${ }^{25}$. Ci drudzy, tzw. apostolscy, wyposażeni byli w specjalne pełnomocnictwa nadane przez władze kościelne dotyczące przypadków zastrzeżonych Stolicy Apostolskiej lub biskupom miejsca. Aleksander VI już w roku 1493 zezwolił konwentowi jasnogórskiemu na trzech lub czterech takich spowiedników ${ }^{26}$. W omawianym tutaj okresie szereg przywilejów dla spowiedników jasnogórskich wydali w latach 1625-1665 papieże Urban VIII i Aleksander VII ${ }^{27}$. Na podstawie pozwolenia wydanego w dniu 17 czerwca 1636 roku przez kard. Izydora ze św. Balbiny, za zgodą papieża Urbana VIII spowiednicy jasnogórscy mogli rozgrzeszać i przyjmować do Kościoła wszystkich heretyków oraz czytać książki z Indeksu Ksiąg Zakazanych ${ }^{28}$. Ojciec Andrzej Gołdonowski (zm. 1660) zaświadczył w jednym ze swoich traktatów maryjnych, że przez 15 lat swojej posługi jako spowiednika apostolskiego pojednał z Kościołem ponad trzy tysiące takich osób ${ }^{29}$. Z długiej listy zasłużonych spowiedników jasnogórskich ${ }^{30} \mathrm{w}$ omawianym okresie wymienić można np.: o. Stanisława Oporowskiego (zm. 1552) ${ }^{31}$, o. Mel-

${ }^{25}$ S. Szafraniec, Konwent paulinów, s. 63-64.

26 Zbiór dokumentów Zakonu Paulinów w Polsce, t. 2: 1464-1550, oprac. J. Zbudniewek, Warszawa 2004, s. 263-264.

${ }^{27}$ Facultates paenitentiariis apostolicis Clari Montis Częstochoviensis ab Urbano octavo PP... AJG 779; A. Jędrzejewski, Jasna Góra. Historia klasztoru i cudownego obrazu Matki Boskiej Częstochowskiej, Częstochowa 1946, s. 217.

28 Actorum Provinciae Polonae, t. 1: 1625-1641, AJG 741, s. 12-15.

29 Summariusz Historiey, o obrazie Panny Maryey, który iest na Jasnej Górze Częstochowskiey..., Kraków 1639, s. 128-129.

30 S. Szafraniec, Konwent paulinów, s. 65-66; G. Prus, Polska prowincja paulinów, s. 79.

31 A. Eggerer, Roczniki Paulińskie, s. 224. 
chiora z Zegrza (zm. 1630) ${ }^{32}$, o. Walentego z Warty (zm. 1634) o. Aleksandra Convasiusa (zm. 1647) ${ }^{34}$, wspominanego już wyżej o. Andrzeja Gołdonowskiego (zm. 1660) ${ }^{35}$, o. Karola Trafarowicza (zm. 1669) ${ }^{36}$, o. Mikołaja Wręczyckiego (zm. 1670) ${ }^{37}$, o. Teofila Wilczewskiego (zm. 1673), wytrwałego spowiednika obcokrajowców, biegle władającego językiem niemieckim ${ }^{38}$, o. Franciszka Pudłowskiego (zm. 1679) ${ }^{39}$, o. Mariana Pokorskiego (zm. 1689) ${ }^{40}$ czy też o. Ambrożego Nieszporkowicza (zm. 1703)

Równie ważna była posługa jasnogórskich kaznodziejów, którzy często okazywali się gorliwymi piewcami Matki Najświętszej i skutecznymi narzędziami w Jej misji prowadzenia ludzi do Boga. Konkretne wskazania dotyczące kaznodziejów znajdowały się w potrydenckich konstytucjach paulińskich ${ }^{42}$. W zakonie paulińskim istniał specjalny urząd kaznodziejów zwyczajnych. W późniejszym czasie (wiek XVIII) wprowadzony zostanie dodatkowo urząd kaznodziei zastępczego zwanego również świątecznym. W roku 1577, wizytując klasztor jasnogórski, bp Stanisław Karnkowski nakazał ustanowienie w sanktuarium stałego kaznodziei, a o kaznodziejach pomocniczych wspominał w czasie swojej wizytacji w roku 1593 kard. Radziwiłł ${ }^{43}$. Jasna Góra miała już jednak stałych kaznodziejów wcześniej, na pewno w pierwszej połowie wieku XVI, czego dowiódł o. J. Zbudnie-

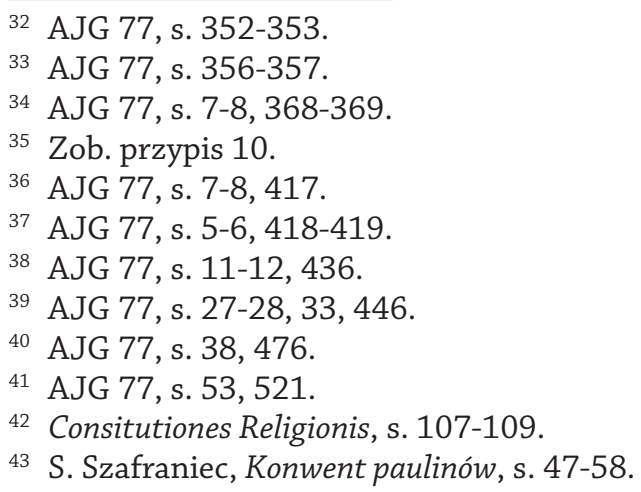

43 S. Szafraniec, Konwent paulinów, s. 47-58. 
wek $^{44}$. Kaznodziejów dla poszczególnych klasztorów mianowano na kapitule prowincjalnej. Do ich obowiązków należało wygłaszanie kazań w czasie liturgii. W roku 1689 otrzymają przywilej zwolnienia z chórowej modlitwy na dwa dni przed wygłoszeniem kazania, a w roku 1725 na trzy dni. W celu gruntownego przygotowania do podejmowanej posługi potrzebne było stale podejmowane studium, pogłębianie wiedzy poprzez stosowną lekturę. Do dyspozycji kaznodziejów służyła zatem dobrze wyposażona biblioteka klasztorna. Kaznodzieje mieli odznaczać się również odpowiednio przykładnym stylem życia. Niektórzy ogłaszali swoje kazania drukiem ${ }^{45}$. Podobnie jak w przypadku spowiedników, można wymienić wielu szczególnie zasłużonych jasnogórskich kaznodziejów ${ }^{46}$. Do najwybitniejszych należą: o. Stanisław Oporowski, o. Mikołaj z Wilkowiecka (zm. 1601) ${ }^{47}$, o. Szymon Mielecki (zm. 1612) $)^{48}$, o. Walenty z Warty, o. Dionizy Łobżyński (zm. 1654) ${ }^{49}$, o. Karol Trafarowicz, o. Sebastian Stawicki (zm. 1670) ${ }^{50}$, o. Stanisław Miąszowski (zm. 1689) ${ }^{51}$, o. Ambroży Nieszporkowicz, o. Tobiasz Czechowicz, o. Adam Graczyński (zm. 1719) ${ }^{52}$.

Dużą wagę przywiązywano też do oprawy muzycznej celebrowanej liturgii oraz nabożeństw odprawianych w sanktuarium. Uroczyste celebracje uświetniała muzyka i śpiew członków ka-

44 J. Zbudniewek, Paulini XVI i XVII wieku w dziele, s. 113.

45 Consitutiones Religionis, s. 107-109; S. Szafraniec, Konwent paulinów, s. $47-53$.

46 S. Szafraniec, Konwent paulinów, s. 53-60; G. Prus, Polska prowincja paulinów, s. 78.

${ }^{47}$ AJG 77, s. 336-337.

48 AJG 77, s. 338-339; K. Matecki, Postylle ojca Szymona Mieleckiego na tle kaznodziejstwa polskiego XVI wieku, „Studia Claromontana” XXI (2003), s. 5-58.

49 AJG 77, s. 21-22, 385.

${ }^{50}$ AJG 77, s. 19-20, 421-423.

51 AJG 77, s. 27-28, 33-34, 475.

52 AJG 77, s. 55, 562. 
peli, której początki sięgają drugiej połowy wieku XVI. Działało w niej wielu utalentowanych muzyków, zarówno świeckich, jak i zakonnych. Znakomitą jednak większość członków kapeli, zarówno wokalistów, jak i instrumentalistów, w tym jasnogórskich organistów, stanowili muzycy zakonni. Całością poczynań kapeli przewodził tzw. magister capelle, którym z zasady był jeden z paulinów. Dobór repertuaru muzycznego należał do dyrygentów. Komponowali oni sami lub sprowadzali nuty $z$ innych ośrodków albo też pozyskiwali kompozytorów dla potrzeb działalności kapeli53. Wśród wielu innych trzeba wymienić następujących paulińskich kompozytorów, muzyków i śpiewaków zasłużonych w tym okresie dla kapeli jasnogórskiej: o. Szymon Neapolitanus (zm. 1621), wokalista i kompozytor pieśni religijnych ${ }^{54}$; o. Melchior z Zegrza (zm. 1630), organista i kompozytor utworów wielogłosowych oraz pieśni chorałowych ${ }^{55}$; o. Piotr z Wieruszowa (zm. 1633), wokalista, kantor, dyrygent, magister capellae ${ }^{56}$; o. Jan z Zegrza (zm. 1633), kompozytor, muzyk, nauczyciel muzyki, dyrygent kapeli jasnogórskiej, magister capellae $^{57}$; o. Kacper Aleksandrowicz (zm. 1652), kompozytor, wokalista, kantor, trębacz, organista, dyrygent, magister capellae, nauczyciel. Wybudował piękny pozytyw w kaplicy Matki Bożej5;

53 Por. P. Podejko, Nieznani muzycy polscy. Kompozytorzy, dyrygenci, instrumentaliści, wokaliści 1572-1820, w: Z dziejów muzyki polskiej, z. 11, Bydgoszcz 1966; Kapela wokalno-instrumentalna paulinów na Jasnej Górze. (skrót pracy doktorskiej), Kraków 1977; Kapela wokalno-instrumentalna na Jasnej Górze, „Studia Claromontana” XIX (2001), s. 5-423.

54 AJG 77, s. 342-343; P. Podejko, Nieznani muzycy polscy, s. 71; tenże, Kapela wokalno-instrumentalna, s. 264.

55 AJG 77, s. 352-353; P. Podejko, Nieznani muzycy polscy, s. 111; tenże, Kapela wokalno-instrumentalna, s. 265.

56 AJG 77, s. 354-355; P. Podejko, Nieznani muzycy polscy, s. 104-105; tenże, Kapela wokalno-instrumentalna, s. 266.

57 AJG 77, s. 23, 354-355; P. Podejko, Nieznani muzycy polscy, s. 111; tenże, Kapela wokalno-instrumentalna, s. 265.

58 AJG 77, s. 1-2, 377; ASk B 245, s. 395-396; P. Podejko, Nieznani muzycy polscy, s. 15-16; tenże, Aleksandrowicz Kasper, w: Encyklopedia katolicka, 
o. Baltazar Nowogorski (zm. 1666), organista, wokalista, kantor, nauczyciel i doskonały znawca śpiewu wielogłosowego ${ }^{59}$; o. Marinus Kornicki (zm. 1671), organista, kompozytor ${ }^{60}$; o. Władysław Leszczyński (zm. 1680), organista, wokalista, kantor, dyrygent, magister capellae, nauczyciel muzyki i kolekcjoner instrumentów muzycznych. Był jednym z najwybitniejszych paulińskich kompozytorów tego okresu. Komponował m.in. utwory maryjne: Sancta Maria a 12 oraz In festis Beatissimae V[irginis] M[ariae] (hymn Ave maris stella) na cztery gł. chór mieszany a cappella ${ }^{61}$; o. Bogusław Nigrynus (zm. 1681), muzyk, wokalista, kantor, wybitny znawca śpiewu chorałowego i muzyki wielogłosowej ${ }^{62}$; o. Alfons Reszciński (zm. 1691), instrumentalista, wokalista, kantor, kompozytor ${ }^{63}$; o. Atanazy Ambrożycz (zm. 1694), skrzypek, wokalista, kantor, nauczyciel muzyki, dyrygent, magister

t. 1, Lublin 1973, s. 346; tenże, Kapela wokalno- instrumentalna, s. 267. 59 AJG 77, s. 13-14, 411; P. Podejko, Nieznani muzycy polscy, s. 72; tenże, Kapela wokalno-instrumentalna, s. 269.

${ }^{60}$ AJG 77, s. 19-20, 423; P. Podejko, Nieznani muzycy polscy, s. 51; tenże, Kapela wokalno-instrumentalna, s. 271.

${ }_{61}$ AJG 77, s. 13-14, 451; P. Podejko, Nieznani muzycy polscy, s. 57-58; K. Mrowiec, Twórczość muzyczna o. Aleksandra Władysława Leszczyńskiego kompozytora jasnogórskiego z XVII wieku (na przykładzie „Mandatum novum”), „Studia Claromontana” I (1981), s. 202-210; tenże, Missa per octavas o. Aleksandra Władysława Leszczyńskiego, „Studia Claromontana" VI (1985), s. 223-239; P. Podejko, Katalog tematyczny kapeli, pozycja 828, s. 332; J. Zbudniewek, Leszczyński (Lesczyński) Szymon, w: Słownik artystów polskich i w Polsce działających (zmartych przed 1966 r.). Malarze, rzeźbiarze i graficy, t. 5, Warszawa 1993, s. 67; Z. Szweykowski, Leszczyński Aleksander, w: Encyklopedia muzyczna PWM, Część biograficzna, t. 5 - „KLE”, Kraków 1997, s. 337; P. Podejko, Kapela wokalno-instrumentalna, s. 269; J. Zbudniewek, Leszczyński Aleksander Władysław, w: Encyklopedia katolicka, t. 10, Lublin 2004, s. 857.

62 AJG 77, s. 452; P. Podejko, Nieznani muzycy polscy, s. 71.

${ }_{63}$ AJG 77, s. 57, 479; P. Podejko, Nieznani muzycy polscy, s. 85; tenże, Kapela wokalno-instrumentalna, s. 277. 
capellae $^{64}$; o. Maksymilian Jowiński (zm. 1691), organista, dyrygent, kompozytor ${ }^{65}$.

\section{Piśmiennictwo maryjne}

Wśród paulinów polskich omawianego okresu, w tym także na Jasnej Górze znajdują się autorzy dzieł teologicznych, ascetycznych, historycznych lub okolicznościowych kazań wydawanych drukiem. Dominującym przedmiotem zainteresowań, w którym się specjalizowali, była tematyka maryjna. Na publikacje o tej tematyce w sanktuarium jasnogórskim zapewne istniało spore zapotrzebowanie, zważywszy licznie przybywających tutaj pielgrzymów. Wydawano zatem szereg traktatów i panegiryków maryjnych, dzieł kaznodziejskich, tekstów mariologicznych, opisów historycznych dotyczących wizerunku jasnogórskiego i jego kultu. Podejmowano tematykę wielkości Maryi i Jej miłości do powierzonego Jej opiece ludu, w tym szczególnie narodu polskiego. Opisywano liczne przykłady Jej nadprzyrodzonych interwencji, wyrazów troski wobec Rzeczypospolitej, wysłuchanych modlitw Jej czcicieli. Podejmowano polemikę z reformatorami, broniąc czci i kultu Bożej Matki ${ }^{66}$. Wśród paulińskich pisarzy tego czasu da się zauważyć sporą liczbę piewców Jasnogórskiej Bogurodzicy. Oprócz wspomnianych już wcześniej wybitnych kaznodziejów jasnogórskich, których kazania zostały opublikowane, jak np. o. Szymon Mielecki, który wydał w latach 1599-1600 Postilla Catholica pars aestivalis oraz Postylla Catholica de Sanctis

${ }^{64}$ AJG 77, s. 46, 487-488; P. Podejko, Nieznani muzycy polscy, s. 16-17; tenże, Ambrożyc Atanazy, w: Encyklopedia katolicka, t. 1, Lublin 1973, s. 417; tenże, Kapela wokalno-instrumentalna, s. 276.

65 AJG 66, k. 17-18; AJG 77, s. 79, 478; AJG 761, k. 63; AJG 192, s. 38-39.

66 Por. J. Zbudniewek, Paulini XVI i XVII wieku w dziele, s. 101-114, 125-131. 
ukończone w roku $1600^{67}$, trzeba wymienić następujących autorów i ich dzieła: o. Andrzej Żymicjusz (zm. 1625) - Skarbnica kościoła Jasnej Góry Częstochowskiego, w której się zamyka historia o cudownym obrazie Panny Marii..., Kraków 161868; o. Paulin Kłodawski - Mariologia seu conclusiones ex angelica salutatione Deiparae Virginis deprompta..., Kraków 162669; o. Dionizy Łobżyński - Triumphus quem divae suae Częstochoviensi..., Kraków 1644; Przenosiny Triumphalne Naycudownieyszego w Krolestwie Polskim obrazu Bogarodzice Panny Maryey..., Kraków 1644; Novus amphion Divae Claromontanae sub auspiicis..., 1646; Dies Natalis, Abo Panegiryk Kościelny o Narodzeniu Bogarodzicy Panny Maryey..., Kraków 165070; o. Mikołaj Staszewski - Nabożeństwo do

67 K. Matecki, Postylle ojca Szymona Mieleckiego, s. 5-58; G. Prus, Polska prowincja paulinów, s. 86.

68 AJG 77, s. 346-347; AJG 2096, k. 1-4v, 13v-15v; ASk 169, s. 99-100; J. Zbudniewek, Żymicjusz Andrzej, w: Słownik polskich teologów katolickich, t. 4, Warszawa 1983, s. 561; tenże, Andrzej Zimicius nieznany dziejopis obrazu jasnogórskiego, w: Prace naukowe Wyższej Szkoty Pedagogicznej w Częstochowie. Zeszyty Historyczne, z. 4: 1997, s. 489-497; J. Zdanowicz, O. Andrzej Zymicjusz i jego dzieło o jasnogórskim obrazie, Warszawa 1997, maszynopis; B. Zakrzewska, Zagadnienia religijno-patriotyczne w literaturze jasnogórskiej do końca XVII wieku, cz. 1, „Studia Claromontana" XXV (2007), s. 531-532; taż, Zagadnienia religijno-patriotyczne w literaturze jasnogórskiej do końca XVII wieku, cz. 2, „Studia Claromontana" XXVI (2008), s. 304.

69 AJG 77, s. 9-10, 375-376; K. Estreicher, Bibliografia polska, t. 19, s. 301; J. Zbudniewek, Kłodawski Paulin Benedykt, w: Słownik polskich teologów katolickich, t. 2, Warszawa 1982, s. 293; J. Zbudniewek, Kłodawski Paulin, w: Encyklopedia katolicka, t. 9, Lublin 2002, s. 188.

70 AJG 77, s. 21-22, 385; AJG 752, s. 3-215; K. Estreicher, Bibliografia polska, t. 21, s. 363-366; H. Czerwień, Łobżyński Jan, w: Polski Słownik Biograficzny, t. 18, Wrocław 1973, s. 379-380; E.J. Osiadły, Znaczenie Jasnej Góry w religijności i kulturze polskiej według nauki o. Jana Dionizego Łobżyńskiego (1593-1654), „Studia Claromontana” III (1982), s. 104-124; B. Zakrzewska, Zagadnienia religijno-patriotyczne, cz. 1, s. 536-537, 544, 563, 578-579, 605; taż, Zagadnienia religijno-patriotyczne, cz. 2, s. 219-239, 309-317. 
Najświętszej Panny Marii z różnych ksiąg zebrane (druk nieznany $)^{71}$; o. Andrzej Gołdonowski - Summariusz Historiey, o obrazie Panny Maryey, który iest na Jasnej Górze Częstochowskiey..., Kraków 1639; Diva Claromontana..., Kraków 1642; Historie imaginis Brdoviensis (druk nieznany) ${ }^{72}$; o. Augustyn Kordecki - Nowa Gigantomachia contra Sacram Imaginem Deipare Virginis a Santo Luca depictam, Kraków 1657³; o. Ambroży Nieszporkowicz - Dziennik Anielski, w którym do Króla i Królowej Anielskiej i Aniołów Świętych krótkie codzienne zamykają się nabożeństwa..., Kraków 1669-1671; Nuptialis Clari Montis apparatus..., Kraków 1670; Officina emblematum, qua precipuos Virginis et Matris Dei Mariae titulos et...,

${ }^{71}$ AJG 77, s. 7-8, 396; K. Estreicher, Bibliografia polska, t. 29, s. 219; J. Zbudniewek, Staszewski Mikołaj, w: Słownik polskich teologów katolickich, t. 4, Warszawa 1983, s. 196-197; tenże, Staszewski Mikołaj, w: Polski Słownik Biograficzny, t. 42, Warszawa-Kraków 2003-2004, s. 527-530.

72 AJG 77, s. 3-4, 401-402; K. Estreicher, Bibliografia polska, t. 17, s. 215-217; K. Kaczmarczyk, Gołdonowski Andrzej, w: Polski Słownik Biograficzny, t. 8, Wrocław 1959, s. 246-247; J. Zbudniewek, Gołdonowski Andrzej, w: Słownik polskich teologów katolickich, t. 1, Warszawa 1981, s. 552-554; F. Opiłowski, Gołdonowski Andrzej, w: Encyklopedia katolicka, t. 5, Lublin 1989, s. 1270-1271; G. Prus, Życie i twórczość o. Andrzeja Gołdonowskiego, Kraków 2001, maszynopis, s. 62-108; B. Zakrzewska, Zagadnienia religijno-patriotyczne, cz. 1, s. 532-534; taż, Zagadnienia religijno-patriotyczne, cz. 2, s. 171-194, 236-237.

73 AJG 77, s. 13-14, 429-435; A. Kordecki, Nowa Gigantomachia contra Sacram Imaginem Deipare Virginis a Santo Luca depictam, Cracovia 1657, wyd. w tłum. J. Łebkowskiego jako Pamiętnik oblężenia Częstochowy, Częstochowa 1991; K. Estreicher, Bibliografia polska, t. 20, s. 87-88; Bibliografia Literatury Polskiej. Nowy Korbut. Piśmiennictwo Staropolskie, t. 2, Warszawa, 1964, s. 390-392; A. Kersten, Kordecki Klemens, w: Polski Słownik Biograficzny, t. 14, Wrocław 1968-1969, s. 53-151; E. Jelonek, Kto jest autorem „Nowej Gigantomachii”? Znieksztatcony pamiętnik o. Kordeckiego, „Nasza Przeszłość” XXXI (1969), s. 75-99; J. Zbudniewek, Kordecki Augustyn Klemens, w: Słownik polskich teologów katolickich, t. 2, Warszawa 1982, s. 355-356; tenże, Kordecki Augustyn, w: Encyklopedia katolicka, t. 9, Lublin 2002, s. 837-838; B. Zakrzewska, Zagadnienia religijno-patriotyczne, cz. 1, s. 537-539; taż, Zagadnienia religijno-patriotyczne, cz. 2, s. 239-285. 
Kraków 1680; Analecta Mensae Reginalis seu historia imaginis Divae Claromontanae Mariae a Divo..., Kraków 1681; Collectanea in Sacram Apocalipsim D. Joannis Apostoli et Evangelistae dilecti a Domino Jesu Christo..., Tyrnawa 1682; toż w j. pol. Odrobiny Stołu Królewskiego, abo historia o cudownym obrazie N. Panny Marii Częstochowskiej..., Kraków 1683; Officina emblematum, qua precipuos Virginis et Matris Dei Mariae titulos et... (tytuł jak wyżej, ale treść publikacji jest różna) Kraków 1691; Anagramatum ex Angelica salutatione Ave Maria gratia plena...; toż pt.: Fragmenta cogitationum seu anagramata ex angelica..., Kraków 1699, oraz prawdopodobnie, przypisywane mu Salve Regina, Wrocław $1664^{74}$.

Wyrazem miłości i czci do Matki Bożej, a jednocześnie chęci upamiętnienia przejawów Jej niezwykłego wstawiennictwa u Boga stała się praktyka zapisywania cudownych zdarzeń związanych z obrazem jasnogórskim w specjalnej Księdze Cudów (Miraculorum BMV). Księga ta pisana wieloma rękami jest do dziś cennym świadectwem działania nadprzyrodzonego na tym miejscu oraz wiary jasnogórskich pielgrzymów. Wśród wielu dokonujących wpisów w Księdze Cudów można wymienić np: o. Szymona Mieleckiego (zm. 1612), który wpisał tam 72 świadectwa cu-

${ }^{74}$ K. Estreicher, Bibliografia polska, t. 23, s. 134-139; K. Szafraniec, Nieszporkowic (Nieszporkowicz) Szymon, w: Polski Słownik Biograficzny, t. 23, Wrocław 1978, s. 66-67; J. Zbudniewek, Nieszporkowicz Ambroży Szymon, w: Słownik polskich teologów katolickich, t. 3, Warszawa 1982, s. 210-212; T.D. Łukaszuk, Tytuły prawne królewskiej godności Maryi wedtug O. Ambrożego Nieszporkowicza, „Studia Claromontana” II (1982), s. 223-247; E. Jelonek, Pieśń o. Ambrożego Nieszporkowicza na cześć króla Sobieskiego (z okazji trzechsetlecia Jasnej Góry), „Studia Claromontana” IV (1983), s. 178-184; T.D. Łukaszuk, Życie i twórczość Ambrożego Nieszporkowicza, „Dissertationes Paulinorum” II (1989), s. 31-78; M. Stepnowski, „Odrobiny stołu królewskiego” o. Ambrożego Nieszporkowicza (1643-1703). Analiza krytyczna, „Studia Claromontana” XXI (2003), s. 59-153; Bibliografia Zakonu Paulinów, s. 810-819; B. Zakrzewska, Zagadnienia religijno-patriotyczne, cz. 1, s. 540-543, 557-620; taż, Zagadnienia religijno-patriotyczne, cz. 2, s. 301-306, 319-321. 
downych zdarzeń ${ }^{75}$, o. Adama Zawadę (zm. 1651), który wpisał 85 takich świadectw $^{76}$ czy też o. Mikołaja Staszewskiego, który zamieścił tam aż 118 relacji o cudach ${ }^{77}$.

\section{Cudowna obrona}

Obrona sanktuarium jasnogórskiego przed Szwedami w dniach 18 listopada - 27 grudnia 1655 roku była wyjątkowym sposobem okazania czci wobec Matki Bożej. Próba napaści na święte miejsce, tak drogie dla katolików w całej Rzeczypospolitej, przez protestanckich Szwedów (niestety pomagali im również katolicy i to z Polski) była faktem dodatkowo bulwersującym społeczeństwo katolickie w całym kraju. Wydarzenie to, choć z militarnego punktu widzenia może niemające wielkiego znaczenia, okazało się punktem zwrotnym w całej kampanii wojennej wojny polsko-szwedzkiej, a w wymiarze religijnym okazało się momentem symbolicznym dla kultu maryjnego w całej Rzeczypospolitej. Odwaga i męstwo o. Augustyna Kordeckiego oraz załogi twierdzy jasnogórskiej, w tym paulińskich zakonników, przeszły do historii. Obrona sanktuarium zakończyła się sukcesem. Paulini ze swoim wybitnym przeorem - dowódcą dokonali tu rzeczy wielkiej i stali się na wieki symbolem bohaterstwa w walce o niepodległość ojczyzny. Ta zwycięska obrona szybko została uznana za cudowną. Niczego nie ujmując obrońcom, ich walorom wojskowym i fachowości, a także uprzedniej opatrznościowej decyzji o budowie ob-

75 J. Zbudniewek, Kopiarze dokumentów, s. 84; tenże, Szymon Mielecki pauliński kopista i bibliofil z przełomu XVI i XVII wieku, w: Bibliologia dyscyplina integrująca. Studia ofiarowane Profesor Barbarze Bieńkowskiej, Warszawa 1993, s. 31-40; B. Zakrzewska, Zagadnienia religijno-patriotyczne, cz. 1, s. 529-531; taż, Zagadnienia religijno-patriotyczne, cz. 2, s. 171-183.

${ }^{76}$ AJG 77, s. 3-4, 376; J. Zbudniewek, Kopiarze dokumentów, s. 91-92.

77 J. Zbudniewek, Kopiarze dokumentów, s. 87-88. 
warowań i ich solidnemu wykonaniu, fakty, które zrelacjonowali nam kronikarze i historycy, dają podstawę, by obronę tę uznać za cudowną nawet wbrew wszelkim malkontentom ${ }^{78}$.

\section{Zakończenie}

Paulini jasnogórscy w omawianym okresie XVI-XVII wieku, w czasie zawieruchy religijnej spowodowanej wybuchem reformacji, w sposób wyraźny stanęli po stronie Kościoła rzymskiego. Poprzez podjętą reformę życia zakonnego odpowiedzieli na wezwanie Kościoła do gorliwej realizacji otrzymanego powołania. A przez różne formy działania apostolskiego, na przekór reformacyjnym modom, przyczynili się do wzrostu czci Matki Bożej w Jej jasnogórskim wizerunku oraz odnowy Kościoła w Rzeczypospolitej.

78 Por. A. Kordecki, Nowa Gigantomachia; S. Kobierzycki, Obsidio Clari Montis Częstochoviensis Deipare imaginis a divo Lucadepictate celeberrimi, Gdańsk 1659, wyd. w tłum. K. Chmielewskiej, E. Rygał jako Obsidio Clari Montis, Oblężenie Jasnej Góry, Kraków 2007; W. Kochowski, Annalium Poloniae Climacter secundus. Bella Sueticum, Transyluanicum, Moschouiticum..., Cracovia 1683, wyd. w tłum. L. Kukulskiego jako Lata Potopu 1655-1657, Warszawa 1966; Bibliografia piśmiennictwa Jasnej Góry i jej obrońcy o. Augustyna Kordeckiego za lata 1655-1977, oprac. H. Czerwień, J. Zbudniewek, Warszawa 1977; Przestanie Jubileuszu 350-lecia zwycięskiej obrony Jasnej Góry (1655), red. Z.Sz. Jabłoński, Częstochowa 2005; Materiały z sesji n.t. Przemiany religijno-społeczne w dobie kontrreformacji do połowy XVII wieku z okazji 400-lecia urodzin o. Augustyna Kordeckiego (Jasna Góra 13 XII 2003), „Studia Claromontana” XXIII (2005), s. 7-163; B. Zakrzewska, Zagadnienia religijno-patriotyczne w literaturze jasnogórskiej do końca XVII wieku, cz. 2, s. 239-285. 


\section{The Marian Service of the Pauline Fathers from Jasna Góra in the Post-Trent Time}

The time of reforms in the Catholic Church after the Council of Trent (1545 - 1563) and the Counter-Reformation was for the Pauline Order, including the Polish province, a period of undertaking new tasks: pastoral, scientific and cultural. The Polish province enjoyed a boom then, which was to reach its climax in the eighteenth century. For the Paulines from Jasna Góra it was a time of intensive pastoral work on various levels, always in the service of the Mother of God, worshiped in the Icon of Jasna Góra for several centuries. When the Reformation criticised Catholic forms of piety, including the lively cult devoted to the Mother of God, the Pauline Fathers remained faithful defenders of their Lady and to the pious tradition of Marian worship in the Church. To honor the Holy Mother of God Pauline undertook numerous construction initiatives which were to improve the functioning of the Shrine, embellishing it and providing necessary protection. They zealously undertook the sacramental and preaching ministry to pilgrims visiting the Sanctuary. They strove for the splendor of God's service in the Sanctuary, among others through impressive musical setting. They published printed Works on Marian topics. And when it was necessary, they defended the glory of the Blessed Virgin, protecting the Sanctuary against the Swedish invaders by risking their lives. 